\title{
Soil nitrogen response to shrub encroachment in a degrading semi-arid grassland
}

\author{
Thomas Turpin-Jelfs ${ }^{1}$, Katerina Michaelides ${ }^{1,2}$, Joel A. Biederman ${ }^{3}$, and Alexandre M. Anesio ${ }^{1,4}$ \\ ${ }^{1}$ School of Geographical Sciences, University of Bristol, Bristol, BS8 1SS, UK \\ ${ }^{2}$ Earth Research Institute, University of California Santa Barbara, Santa Barbara, CA, USA \\ ${ }^{3}$ Southwest Watershed Research Center, United States Agricultural Department, Tucson, AZ, USA \\ ${ }^{4}$ Department of Environmental Science, Aarhus University, 4000 Roskilde, Denmark
}

Correspondence: Thomas Turpin-Jelfs (thomas.turpin-jelfs@ bristol.ac.uk)

Received: 9 July 2018 - Discussion started: 23 July 2018

Revised: 3 December 2018 - Accepted: 7 January 2019 - Published: 24 January 2019

\begin{abstract}
Transitions from grass- to shrub-dominated states in drylands by woody plant encroachment represent significant forms of land cover change with the potential to alter the spatial distribution and cycling of soil resources. Yet an understanding of how this phenomenon impacts the soil nitrogen pool, which is essential to primary production in arid and semi-arid systems, is poorly resolved. In this study, we quantified how the distribution and speciation of soil nitrogen, as well as rates of free-living biological nitrogen fixation, changed along a gradient of increasing mesquite (Prosopis velutina Woot.) cover in a semi-arid grassland of the southwestern US. Our results show that site-level concentrations of total nitrogen remain unchanged with increasing shrub cover as losses from inter-shrub areas (sum of grass and baresoil cover) are proportional to increases in soils under shrub canopies. However, despite the similar carbon-to-nitrogen ratio and microbial biomass of soil from inter-shrub and shrub areas at each site, site-level concentrations of inorganic nitrogen increase with shrub cover due to the accumulation of ammonium and nitrate in soils beneath shrub canopies. Using the acetylene reduction assay technique, we found increasing ratios of inorganic nitrogen to bioavailable phosphorus inhibit rates of biological nitrogen fixation by freeliving soil bacteria. Overall, these results provide a greater insight into how grassland-to-shrubland transitions influence the soil $\mathrm{N}$ pool through associated impacts on the soil microbial biomass.
\end{abstract}

\section{Introduction}

Degrading dryland landscapes undergo significant ecological transformations typically associated with gradual and irreversible changes in plant community composition (D’Odorico et al., 2013). Woody plant encroachment is a widespread example of dryland degradation, whereby continuous grasslands are progressively replaced by shrubs interspersed by patches of bare soil (Ravi et al., 2010). These plant community changes result in a structurally, physically and biologically different ecosystem which significantly alters the spatial distribution and fluxes of nutrients and the biogeochemical cycling within dryland landscapes, with implications for the ongoing process of land degradation (Eldridge et al., 2011; Michaelides et al., 2012). Nitrogen (N), in particular, is considered the most significant limiting nutrient of primary production and decomposition processes in arid and semi-arid ecosystems (Gebauer and Ehleringer, 2000), yet there is currently limited understanding of how ecosystem transformations associated with land degradation change the distribution, speciation, and cycling of $\mathrm{N}$ (Browning et al., 2008), as well as the associated soil microbial biomass (Li et al., 2017). As drylands occupy $\sim 40 \%$ of Earth's land surface, changes in the nutrient distributions, patterns and cycling within degrading areas have important implications for biogeochemical cycles at the global scale (DelgadoBaquerizo et al., 2013).

Occurring in Africa (Hudak et al., 2003), Asia (Zhang et al., 2016), Australia (Cookson et al., 2006), Europe (Quero et al., 2013), North America (Knapp et al., 2008), and South America (Cabral et al., 2003), extensive research has demon- 
strated that shrub encroachment into grasslands alters the scale of vegetation heterogeneity within the landscape from fine to large scales and changes the microtopography from relatively subdued to high relief as soil mounds develop beneath shrub canopies (Charley and West, 1975; Wainwright et al., 2000; Schlesinger et al., 1996). These changes in both vegetation heterogeneity and microtopography result in modifications to runoff and erosion patterns (Michaelides et al., 2009; Parsons et al., 1996), which directly affect the redistribution of, and patterns in, nutrients within the landscape in favour of shrub functional types (Cross and Schlesinger, 1999; Michaelides et al., 2012; Schlesinger et al., 1996). In addition, shrubs may further concentrate nutrients beneath their canopies through increased inputs of high-quality above- and below-ground detritus (Throop and Archer, 2008). The resulting accumulation of soil organic matter (SOM) in shrub mounds represents an important pool of mineralisable $\mathrm{N}$ that provides shrubs with a competitive advantage over herbaceous plants during times of nutrient limitation (Turnbull et al., 2010).

In terrestrial systems, the availability of inorganic $\mathrm{N}$, defined hereafter as the sum of ammonium $\left(\mathrm{NH}_{4}^{+}-\mathrm{N}\right)$ and nitrate $\left(\mathrm{NO}_{3}^{-}-\mathrm{N}\right)$, is largely controlled by microbial decomposition processes (Vitousek et al., 2002). The dominant decomposers in soil are bacteria and fungi, of which fungi typically exhibit greater carbon (C) : $\mathrm{N}$ ratios than bacteria, as well as enhanced $\mathrm{C}$ use efficiency and reduced rates of nutrient turnover (Waring et al., 2013). As the amount of $\mathrm{N}$ mineralised during decomposition depends on the $\mathrm{C}$ and $\mathrm{N}$ stoichiometry of decomposer organisms relative to that of organic matter (Schulten and Schnitzer, 1997), differences in the relative abundance of fungal and bacterial biomass can potentially modulate soil $\mathrm{N}$ cycling (Waring et al., 2013). Using the phospholipid fatty acid (PLFA) method, Li et al. (2017) demonstrated that the ratio of viable fungi to bacteria for a semi-arid grassland was significantly higher in soil under shrubs than for soils in inter-shrub areas and that soil microbial biomass was positively correlated with concentrations of total $\mathrm{N}$ and available phosphorus (P). However, an understanding of how the fungal and bacterial constituents of the microbial biomass change along a gradient of increasing shrub cover within a semi-arid grassland is currently lacking.

Whilst mineralisation may control the availability of $\mathrm{N}$, biological $\mathrm{N}$ fixation (BNF) by free-living (asymbiotic) soil bacteria and legume-Rhizobium symbioses is the principal input of reactive $\mathrm{N}$ to semi-arid systems (Evans and Ehleringer, 1993), in which rates of symbiotic BNF are approximately an order of magnitude higher than inputs through asymbiotic pathways (Cleveland et al., 1999). Many encroaching shrub species, such as mesquite (Prosopis spp.), are legumes capable of symbiotic BNF, which reduces their dependence on soil $\mathrm{N}$ mineralisation and offers the potential to increase the availability of $\mathrm{N}$ within a system (Blaser et al., 2014). However, since BNF has a high $P$ demand, rates of symbiotic dinitrogen $\left(\mathrm{N}_{2}\right)$ fixation by mesquite have been shown to down-regulate as $\mathrm{N}$ increases relative to concentrations of available P (Geesing et al., 2000). Less studied are the effects of ecosystem transformations on inputs of asymbiotically fixed $\mathrm{N}$ to semi-arid grasslands, which despite being lower than contributions by symbiotic BNF, are still significant due to the small size of the soil $\mathrm{N}$ pool in these systems.

The aim of this study was to assess how a transition from a grass- to shrub-dominated state within a dryland ecosystem impacts the soil $\mathrm{N}$ status and inputs of $\mathrm{N}$ by asymbiotic BNF. Specifically, our objectives were

1. to examine how pools of total $\mathrm{N}, \mathrm{NH}_{4}^{+}-\mathrm{N}$, and $\mathrm{NO}_{3}^{-}-\mathrm{N}$, as well as the microbial biomass, in soil varied across a shrub encroachment gradient; and

2. to determine how the distribution and supply rates of asymbiotically fixed $\mathrm{N}$ varied across a shrub encroachment gradient.

We expected that reductions in grass biomass resulting from higher levels of shrub encroachment would cause soil $\mathrm{N}$ to be progressively redistributed from inter-shrub zones to areas beneath shrub canopies. As the spatial distribution of soil microorganisms is positively influenced by resource availability (Schlesinger and Pilmanis, 1998), we hypothesised the enhanced fertility and environmental conditions in soils under shrubs would support a higher soil microbial biomass and promote $\mathrm{N}$ mineralisation processes, leading to an increased availability of inorganic N. Accordingly, we predicted that rates of asymbiotic BNF would decrease in shrub soils as inorganic $\mathrm{N}$ increased relative to bioavailable P (Smith, 1992).

\section{Materials and methods}

\subsection{Study site description}

Fieldwork was conducted between March and April 2016 at the Santa Rita Experimental Range (SRER; Fig. 1a; $31^{\circ} 54^{\prime} \mathrm{N}, 110^{\circ} 53^{\prime} \mathrm{W}$ ), Arizona, in the southwestern US, a region where the density of mesquite has increased by $>400 \%$ over the past ca. 30 years alone (Resco de Dios et al., 2012). Situated on a bajada comprising $\sim 21000$ ha, the SRER ranges in elevation from 900 to $1400 \mathrm{~m}$ a.s.l. (McClaran, 2003). Mean daily maximum and minimum air temperatures for the years 2008 to 2015 were 25 and $13^{\circ} \mathrm{C}$, respectively. Mean annual precipitation for the same period was $392 \mathrm{~mm}$, with $61 \%$ received during the summer months (July through September). The respective mean daily maximum and minimum summer temperatures between 2008 and 2015 were 31 and $20^{\circ} \mathrm{C}$ (AmeriFlux, http://ameriflux.lbl. gov/data/download-data/, last access: 15 June 2017). Vegetation is dominated by native desert grassland species, such as Rothrock grama (Bouteloua rothrockii Vasey), sideoats grama (B. curtipendula (Michx.) Torr.), Arizona cottontop 


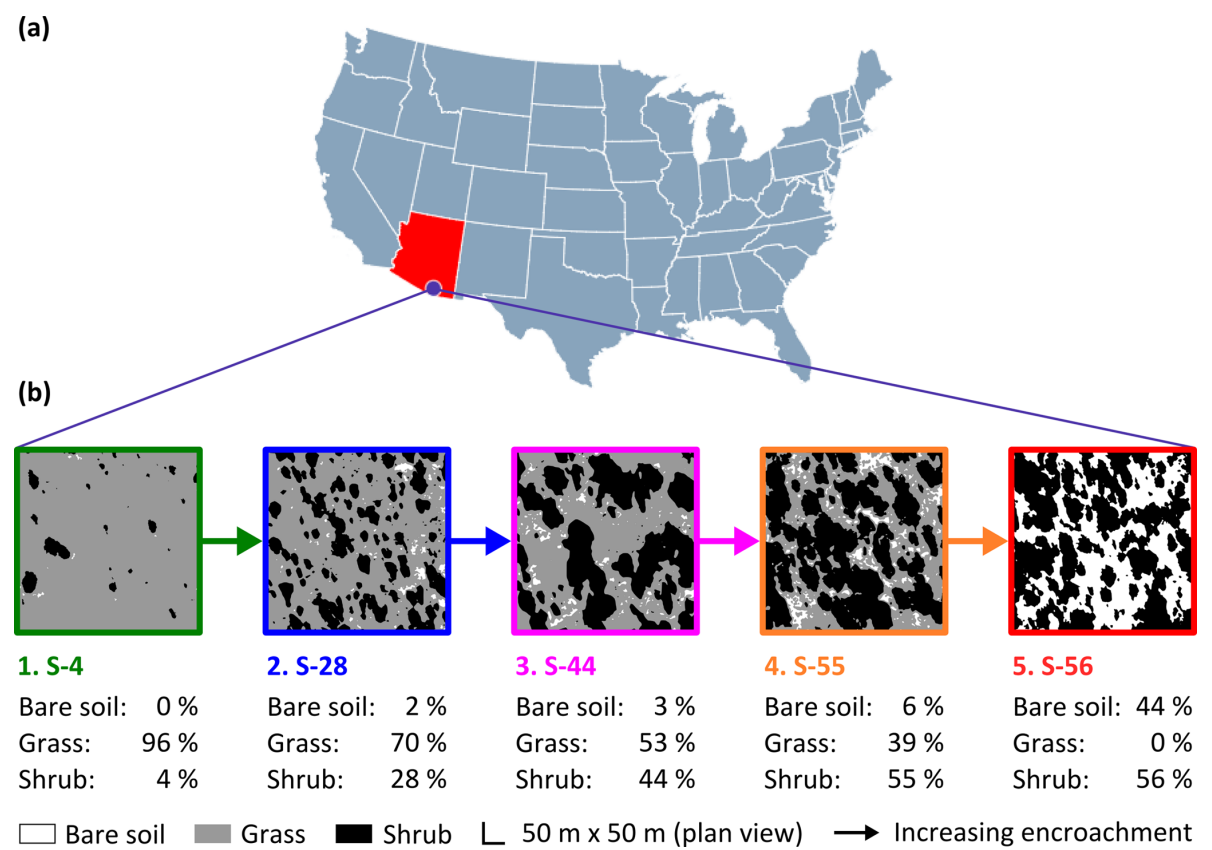

Figure 1. The study site (a) was a semi-arid grassland in the Santa Rita Experimental Range, AZ, US $\left(31^{\circ} 54^{\prime} \mathrm{N}, 110^{\circ} 53^{\prime} \mathrm{W}\right.$; elevation: $\sim 1250 \mathrm{~m}$ a.s.1.). Five sampling sites comprised a gradient of shrub encroachment, where grass cover decreased and bare soil and shrub cover increased between sites 1 and 5 (b). The inter-shrub area of each site is equal to the sum of the percentage of bare soil and grass cover.

\section{(a) 1904}
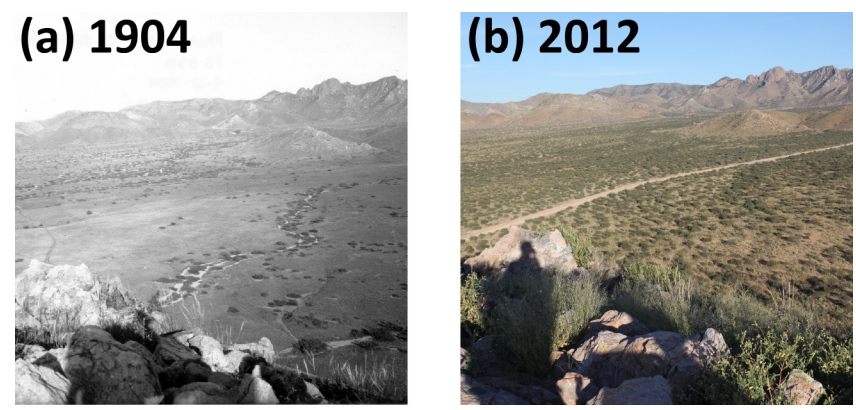

Figure 2. Scattered shrubs replace grasses as dominant vegetation between 1904 (a) and 2012 (b) in the Santa Rita Experimental Range, AZ, US. Facing north-northeast in pastures 6B and 6D. Elevation is $1228 \mathrm{~m}$ a.s.l. (public domain images available from https: //cals.arizona.edu/srer/photos.html, last access: 27 April 2018).

(Digitaria californica (Benth.) Henrard), bush muhly (Muhlenbergia porteri Scribn.), and tanglehead (Heteropogon contortus (L.) Beauv.), as well as the non-native Lehmann love grass (Eragrostis lehmanniana Nees.). Cacti, such as cholla cactus species (Opuntia spp. Mill.), and shrubs, such as velvet mesquite (Prosopis velutina Woot.) and catclaw acacia (Acacia greggii A. Gray), were also present (McClaran et al., 2002).

Encroachment by mesquite within the SRER has been well documented (McClaran, 2003). Velvet mesquite, which was restricted to drainage arroyos in 1903, currently occupies $\sim 35 \%$ of the total grassland area (Fig. 2) and repre- sents the dominant shrub species within the elevation band of 990-1200 ma.s.l. (Browning et al., 2008). The following five sampling sites comprise a gradient of increasing shrub cover representing progressive ecosystem degradation: S-4, S-28, S-44, S-55, and S-56 (Fig. 1b), where the number signifies the percentage of shrub cover. The percentage of shrub canopy and inter-shrub area was calculated for the five sites using high-resolution satellite imagery from Google Earth (2016a-e), which was cropped to the same dimensions and segmented using the Trainable Weka Segmentation plugin for Fiji (http://fiji.sc/Fiji, last access: 27 April 2018). Sobel and Gaussian blur filters were used for edge detection and noise suppression, respectively (Arganda-Carreras et al., 2017). The out-of-bag error for all sites classified was $<2 \%$. Soils at these sites were formed in alluvium from igneous rock of Holocene and Late Pleistocene origins (Batchily et al., 2003) in the Combate-Diaspar complex (CoB), characterised by excellent drainage, sandy loam textures, and $1 \%$ $8 \%$ slopes (SRER Digital Database, https://cals.arizona.edu/ srer/data.html, last access: 26 November 2018). All five sites were situated at $\sim 1250 \mathrm{~m}$ a.s.l., exhibited similar topography, and had the same land use history.

\subsection{Field measurements and sample collection}

To mitigate the effects of directional bias during sampling, a $180 \mathrm{~m}$ transect (horizontal distance) was arranged in a $Y$ configuration at each site, where three $60 \mathrm{~m}$ transects radiated out from plot centres at azimuths of 30,150 , and $270^{\circ}$ 




Figure 3. Plan view of sampling design in which grass and shrub biomass, as well as inter-shrub and shrub soil samples, were obtained from $0.5 \mathrm{~m}^{2}$ and $100 \mathrm{~m}^{2}$ quadrats, respectively (not to scale). The $0.5 \mathrm{~m}^{2}$ quadrats were not fixed but were instead centred within the largest inter-shrub area of each $100 \mathrm{~m}^{2}$ quadrat.

(Fig. 3). Three $100 \mathrm{~m}^{2}$ quadrats were then installed at 10 , 30 , and $50 \mathrm{~m}$ intervals along each transect for the determination of above-ground shrub biomass. Further, a $0.5 \mathrm{~m}^{2}$ quadrat was centred within the largest inter-shrub area of each $100 \mathrm{~m}^{2}$ quadrat for the determination of above-ground grass biomass. The dry weight of each velvet mesquite plant was estimated from stem basal diameter measurements using methods and a site- and species-specific allometric equation reported in McClaran et al. (2013). Similarly, the dry weight of individual bunch grasses was estimated from tussock basal diameter measurements using methods, and a sitespecific multispecies allometric equation reported in Nafus et al. (2009). The sums of the individual shrub and herbaceous constituents were calculated and used to estimate the total mesquite and grass biomass by dry weight for each site, where grass biomass was weighted according to inter-shrub area $\left(\mathrm{kg} \mathrm{m}^{-2}\right)$. Finally, three inter-shrub and shrub surface soil (top $10 \mathrm{~cm}$ ) cores were extracted at equal distances between the stem and drip line on the north side of the mesquite plant with the largest stem basal diameter and along the centre of the $0.5 \mathrm{~m}^{2}$ quadrat, respectively. The extracted cores were then homogenised to create single inter-shrub and shrub samples for each quadrat per site $(n=9)$ and sealed in sterile bags (Whirl-Pak ${ }^{\circledR}$, Lactun, Australia).

\subsection{Soil preparation}

The mechanical sieving method described by Loveland and Whalley (2000) was used to evaluate the coarse fraction ( $>2 \mathrm{~mm}, \mathrm{wt} \%$ ) of each sample. The resulting fine earth fraction $(\leq 2 \mathrm{~mm})$ from each sample was retained for all further analyses. For pH, PLFA, and elemental analyses, the number of inter-shrub and shrub samples per site was reduced to three $(n=3)$ by homogenising the samples collected along each of the three $60 \mathrm{~m}$ transects. Samples were then stored in a dark temperature-controlled environment at $4{ }^{\circ} \mathrm{C}$. Prior to storage, aliquots of $5 \mathrm{~g}$ from each of the $n=9$ and $n=3$ samples were frozen at $-20^{\circ} \mathrm{C}$ and freeze-dried for elemental and PLFA analyses, respectively.

\subsection{Soil characteristics}

Soil $\mathrm{pH}$ was measured in a $1: 5$ soil $: 0.01 \mathrm{MCaCl}_{2}$ suspension after mixing at $20 \mathrm{rpm}$ for $30 \mathrm{~min}$ using a Stuart SB3 rotator (Bennett et al., 2003). Particle-size determination for the fine earth fraction (\%) was measured using a Malvern Mastersizer 3000 laser particle size analyser with a hydro EV pump accessory (Malvern Panalytical, Worcestershire, UK), for which isopropanol was used as the dispersant (Goossens et al., 2014). Water holding capacity (WHC; \%) was estimated using the percentage of sand and clay content of each sample (Saxton and Rawls, 2006), which had been defined according to the USDA-SCS (1982) classification scheme. Soil dry matter content (DMC; \%) was determined for all samples using the gravimetric method described by Rowell (1994). Lastly, as it was not possible to extract intact soil cores, an average bulk density value of $1.33 \mathrm{~g} \mathrm{~cm}^{-3}$ was assumed for all samples using previously published data for the SRER (Wheeler et al., 2007).

\subsection{Elemental analysis}

For each sample, an aliquot of $\sim 100 \mathrm{mg}$ of freeze-dried soil was embrittled using liquid $\mathrm{N}_{2}$ and ground to a flour using a pestle and mortar. Concentrations of soil organic $\mathrm{C}$ (SOC) and total $\mathrm{N}$ were then determined on an elemental analyser (CHNS-O EA 1108 elemental analyzer; Carlo Erba, Milan, IT) in accordance with methods outlined by Hedges and Stern (1984), for which the detection limits were $<0.5 \mu \mathrm{g} \mathrm{g}^{-1}$ for both elements measured. The coefficient of variation (six replicate standards) for $\mathrm{C}$ and $\mathrm{N}$ was $\pm 1.69 \%$ and $\pm 1.36 \%$, respectively.

\subsection{Soil nutrient analyses}

Concentrations of exchangeable $\mathrm{NH}_{4}^{+}-\mathrm{N}$ and $\mathrm{NO}_{3}^{-}-\mathrm{N}$ in soil were extracted with $2 \mathrm{M} \mathrm{KCl}(1: 10 \mathrm{w} / v$ soil : extractant $)$ and determined colourimetrically using a flow injection analyser (Lachat QuikChem 8500 Series 2 FIA system, Loveland, $\mathrm{CO}, \mathrm{US}$ ), for which the coefficient of variation (six replicate standards) for $\mathrm{NH}_{4}^{+}-\mathrm{N}$ and $\mathrm{NO}_{3}^{-}-\mathrm{N}$ was $\pm 0.75 \%$ and $\pm 5.19 \%$, respectively, according to mid-range standards (calibration range: $0-0.5 \mathrm{mg} \mathrm{L}^{-1}$ ). Thus, for each sample, $1 \mathrm{~g}$ of fresh soil was added to $10 \mathrm{~mL}$ of $2 \mathrm{M} \mathrm{KCl}$, shaken for $30 \mathrm{~min}$ at $160 \mathrm{rpm}$, centrifuged for $5 \mathrm{~min}$ at $4500 \mathrm{rpm}$, and filtered to $0.45 \mu \mathrm{m}$ using Whatman WCN plain cellulose nitrate filtrate papers. Extracts were then analysed for $\mathrm{NH}_{4}^{+}-\mathrm{N}$ (QuikChem ${ }^{\circledR}$ method 31-107-06-1-I) using the Berthelot reaction (Willis et al., 1993) and $\mathrm{NO}_{3}^{-}-\mathrm{N}$ (QuikChem ${ }^{\circledR}$ method 31-107-04-1-K) using the cadmium reduction method (Willis and Gentry, 1987). The respective 
detection limits for $\mathrm{NH}_{4}^{+}-\mathrm{N}$ and $\mathrm{NO}_{3}^{-}-\mathrm{N}$ were 0.04 and


sorbed and iron- and aluminium-bound $\mathrm{P}$ ) was sequentially extracted from $0.2 \mathrm{~g}$ of soil using a method adapted from Hedley et al. (1982) and Mumford (2003) as described in Michaelides et al. (2012). The concentrations of the resulting extracts were determined photometrically on a Gallery ${ }^{\mathrm{TM}}$ Plus automated photometric analyzer (Thermo Fisher Scientific, San Jose, CA). The limit of detection for both loosely sorbed, and iron- and aluminium-bound $\mathrm{P}$ was $1.1 \mu \mathrm{g} \mathrm{g}^{-1}$. The coefficient of variation (six replicate standards) for the same fractions were $\pm 0.35 \%$ and $\pm 0.41 \%$, respectively. All samples were blank corrected where blank concentrations exceeded the detection limits.

\subsection{Microbial biomass estimation}

PLFAs were extracted from $2 \mathrm{~g}$ aliquots of each sample using a modified Bligh and Dyer (1959) method as described by Frostegård et al. (1991). Subsequent fractionation and derivatisation was performed according to methods by Dickson et al. (2009) and Christie (1993), respectively. The methyl ester of nonadecane was added at a concentration of $0.1 \mathrm{mg} \mathrm{L}^{-1}$ as an internal standard to quantify the fatty acids. Individual compounds were quantified using a gas chromatograph (GC) equipped with an Agilent VF-23ms column $(60 \mathrm{~m} \times 0.32 \mathrm{~mm} \times 0.15 \mu \mathrm{m}$; helium $(\mathrm{He})$ carrier gas, constant $2 \mathrm{~mL} \mathrm{~min}^{-1}$ flow rate), which was operated for $1 \mathrm{~min}$ at $50^{\circ} \mathrm{C}$ followed by a $10^{\circ} \mathrm{C} \mathrm{min}^{-1}$ ramp to $100^{\circ} \mathrm{C}$ and a $4{ }^{\circ} \mathrm{C} \mathrm{min}^{-1}$ ramp to a final temperature of $250^{\circ} \mathrm{C}$ that was maintained for $15 \mathrm{~min}$. Compound structures were identified based on comparisons with the retention times and mass spectra for authentic laboratory standards. The mass spectra of individual components were obtained using a Thermo Scientific 1300 series GC (column, carrier gas, and operation as above) coupled, using a heated transfer line $\left(260^{\circ} \mathrm{C}\right)$, to a Thermo Scientific ISQ LT quadrupole mass spectrometer scanning in the range of $m / z$ 50-650 with a dwell time of $0.5 \mathrm{~s}$ (current was maintained at $50 \mu \mathrm{A}$ with an ion source temperature of $240^{\circ} \mathrm{C}$ and an electron voltage of $70 \mathrm{eV}$ ). Fatty acids which were $<14 \mathrm{C}$ and $>20 \mathrm{C}$, or which accounted for $<0.5 \%$ of the total peak area, were excluded from the analysis. Bacterial and fungal biomass were defined according to Bååth and Anderson (2003).

\subsection{Acetylene reduction assay}

Due to time and cost constraints, rates of asymbiotic BNF (nitrogenase activity) for inter-shrub and shrub soils were assessed for three sites (S-4, S-44, and S-56) using the acetylene $\left(\mathrm{C}_{2} \mathrm{H}_{2}\right)$ reduction assay technique adapted from Telling et al. (2011). Prior to analysis, any remaining loose plant matter (roots and shoots) was removed from samples using forceps. A sample, control, and kill control (autoclaved at $126^{\circ} \mathrm{C}$ for $30 \mathrm{~min}$ ) were created from each ho- mogenised sample by adding aliquots of fresh soil (equivalent to $7.5 \mathrm{~g}$ dry mass) to $30 \mathrm{~mL}$ serum bottles. Samples were then adjusted to $60 \%$ WHC, sealed using grey butyl stoppers, and crimped shut. In addition, a blank was created by adding $10 \mathrm{~mL}$ of autoclaved Milli-Q water to an empty serum bottle. Serum bottles were placed in an illuminated $\left(0.2 \pm 0.005 \mathrm{~W} \mathrm{~m}^{-2}\right)$ incubator set to $26^{\circ} \mathrm{C} \pm 0.1^{\circ} \mathrm{C}$ (mean of maximum and minimum summer temperatures). Following a $72 \mathrm{~h}$ pre-incubation period, $10 \%$ of the headspace from the sample, blank, and kill control was replaced with $100 \%$ $\mathrm{C}_{2} \mathrm{H}_{2}$ gas, which had been produced by adding Milli-Q water to technical grade calcium carbide (Sigma, St Louis, MO, US), via an airtight syringe. Serum bottles were sampled at $0,3,6,12,20$, and $24 \mathrm{~h}$ intervals, for which $5 \mathrm{~mL}$ of headspace was transferred to pre-evacuated $3.7 \mathrm{~mL}$ Exetainers (Labco, Lampeter, UK). A $1 \mathrm{~mL}$ aliquot of headspace from each Exetainer was then analysed using a Varian 3800 GC (Varian, Inc., Palo Alto, CA, US), where ethylene $\left(\mathrm{C}_{2} \mathrm{H}_{4}\right)$ was separated from $\mathrm{C}_{2} \mathrm{H}_{2}$ using a $6^{\prime} \times 1 / 8^{\prime \prime}, 80 / 100$ mesh HayeSep T column at $85^{\circ} \mathrm{C}$ (He carrier gas). Daily standards of $100 \mathrm{ppm} \mathrm{C}_{2} \mathrm{H}_{4}$ (BOC, Guildford, UK) gave precisions of $<5 \%$. The precision for $100 \mathrm{ppm}$ standards that had been stored in $3.7 \mathrm{~mL}$ for a period of 1 month also gave precisions of $<5 \%$. Rates of $\mathrm{C}_{2} \mathrm{H}_{4}$ production were converted to rates of annual $\mathrm{N}$ fixation $\left(\mathrm{mmol} \mathrm{N} \mathrm{m} \mathrm{N}^{-2} \mathrm{a}^{-1}\right)$ using a theoretical ratio of $3: 1$.

\subsection{Statistical analysis}

Statistical analysis of the data was performed using $\mathrm{R}$ version 3.5.0. The Kruskal-Wallis (KW) $H$ test was used to determine if significant differences occurred for data within the same cover type along the encroachment gradient. When significance was indicated, Dunn's test of multiple comparisons (DT) was applied. The Mann-Whitney (MW) $U$ test was used to make within-site comparisons for data among cover types. Relationships between explanatory and response variables were explored using simple linear regression analysis, for which residuals were inspected for evidence of nonnormality using the Shapiro-Wilk test. For this study, the alpha level was set to 0.05 . All errors reported in the text are 1 median absolute deviation about the median (Crawley, 2005).

\section{Results}

\subsection{Plant biomass}

Vegetation biomass and cover were strongly influenced by the degree of shrub encroachment at each site. Overall, total vegetation (grass and shrub) cover decreased from $100 \%$ to $56 \%$ among end-member sites, as reductions in grass cover exceeded gains in shrub cover (Fig. 1b). The changes in grass and shrub cover were also positively related with grass $\left(R^{2}=0.87\right.$; Fig. $\left.4 \mathrm{c}\right)$ and shrub $\left(R^{2}=0.77\right.$; Fig. $\left.4 \mathrm{~d}\right)$ biomass, respectively. Thus, grass biomass declined from 



Figure 4. Above-ground multispecies grass (a) and Prosopis velutina Woot. (b) biomass by dry weight across a shrub encroachment gradient and according to grass (c) and shrub (d) cover in the Santa Rita Experimental Range, AZ, US $(n=9)$. Boxes denoted with different letters indicate significant differences within biomass classes at $p<0.05$ (Dunn's test). Error bars represent median absolute deviation about the median.

$0.62 \pm 0.19 \mathrm{~kg} \mathrm{~m}^{-2}$ at S-4 to $0 \mathrm{~kg} \mathrm{~m}^{-2}$ at S-56 (Fig. 4a; DT, $p<0.001$ ), whereas shrub biomass increased from $0.02 \pm$ 0.02 to $4.45 \pm 4.19 \mathrm{~kg} \mathrm{~m}^{-2}$ among the same sites (DT, $p<0.001$, Fig. 4b). Lastly, shrub biomass was greater than grass biomass at all sites except $\mathrm{S}-4$, where grass biomass surpassed shrub biomass $(p<0.05)$.

\subsection{Soil characteristics}

Of the soil properties presented in Table 1, only inter-shrub and shrub soil $\mathrm{pH}$ exhibited clear trends with increasing encroachment. Specifically, inter-shrub soil $\mathrm{pH}$ decreased linearly from $6.3 \pm 0.4$ to $4.7 \pm 0.4$ among end-member sites, whereas shrub soil $\mathrm{pH}$ increased from $4.9 \pm 0.1$ to $6.0 \pm 0.2$ along the same gradient. Significant differences in the remaining soil properties of Table 1 did not follow clear trends and occurred only in inter-shrub soils. The sand content of inter-shrub soil at S-28 was lower in comparison with all other inter-shrub soils (DT, $p<0.05$ ). Further, the silt and clay contents of inter-shrub soil at S-28 were greater, relative to other sites, excluding sites S-55 and S-56, respectively (DT, $p<0.05$ ). Lastly, the coarse fraction of inter-shrub soil at S-55 was greater than that of other inter-shrub soils along the encroachment gradient (DT, $p<0.05$ ).
Soil clay content represented the only consistent physical difference among cover types, for which clay content was higher in soils from inter-shrub areas relative to those from beneath shrub canopies (MW, $p<0.05$ for sites S-4 and S$56 ; p<0.01$ for sites S-28, S-44, S-55; Table 1). Changes in other physical soil properties did not exhibit a relationship with increasing encroachment. At S-28, the silt content (MW, $p<0.001)$ and DMC (MW, $p<0.01$ ) of inter-shrub soil were greater than those of the shrub soil; however, the sand content of inter-shrub soil was lower in comparison with shrub soil (MW, $p<0.001$ ). Inter-shrub soil at S-44 exhibited a higher DMC (MW, $p<0.05$ ) and sand content (MW, $p<0.05$ ) than shrub soil for the same site; though the silt content was lower than that of the shrub soil (MW, $p<0.05$ ). Finally, the percentage of coarse fragments differed between inter-shrub and shrub soils at S-4 (MW, $p<0.001)$.

\subsection{Distribution and speciation of nitrogen}

The total $\mathrm{N}$ in shrub soils was more than 2 times greater than that in inter-shrub soils (MW, $p<0.05$ ) at each site along the degradation gradient (Fig. 5a). Further, concentrations of total $\mathrm{N}$ in inter-shrub soils declined proportionally with reductions in grass biomass from $710 \pm 59 \mu \mathrm{g} \mathrm{g}^{-1}$ at S-4 to $344 \pm 43 \mu \mathrm{g} \mathrm{g}^{-1}$ at S-56. Specifically, the total $\mathrm{N}$ content in inter-shrub soil at S-56 was lower in comparison with all other inter-shrub soils (DT, $p<0.05$ ), and concentrations of total $\mathrm{N}$ within inter-shrub soils from sites S- 44 and S-55 were lower than the concentrations observed at S-4 (DT, $p<0.05$ ). In contrast, a non-linear trend was observed in the shrub soil total $\mathrm{N}$ pool, whereby total $\mathrm{N}$ steadily increased from $920 \pm 198 \mu \mathrm{g} \mathrm{g}^{-1}$ in shrub soil at S-4 to $1527 \pm 171 \mu \mathrm{g} \mathrm{g}^{-1}$ at S-55, before declining to $787 \pm 398 \mu \mathrm{g} \mathrm{g}^{-1}$ at S-56; however, these differences were not significant (KW, $p>0.05$ ).

Concentrations of $\mathrm{NH}_{4}^{+}-\mathrm{N}$ did not change with increasing encroachment in either the inter-shrub (KW, $p>0.05)$ or shrub (KW, $p>0.05$ ) soils, where the average of median concentrations in inter-shrub and shrub soils were $1 \mu \mathrm{g} \mathrm{g}^{-1}$ and $3 \mu \mathrm{g} \mathrm{g}^{-1}$, respectively (Fig. 5 b). However, $\mathrm{NH}_{4}^{+}-\mathrm{N}$ concentrations were approximately an order of magnitude higher under shrub canopies compared to inter-shrub areas for all sites (MW, $p<0.05$ ) except S-56 (MW, $p>0.05$ ). Further, shrub soil $\mathrm{NH}_{4}^{+}-\mathrm{N}$ concentrations exhibited greater variability than those of the inter-shrub soils.

Like $\mathrm{NH}_{4}^{+}-\mathrm{N}$, soil $\mathrm{NO}_{3}^{-}-\mathrm{N}$ concentrations were greater in soils beneath shrub canopies than in inter-shrub areas for all sites (MW, $p<0.05$ ) except S-56 (MW, $p>0.05$; Fig. 5c) and the variability in $\mathrm{NO}_{3}^{-}-\mathrm{N}$ in shrub soils was greater than that of their inter-shrub counterparts. However, unlike $\mathrm{NH}_{4}^{+}-\mathrm{N}$, inter-shrub $\mathrm{NO}_{3}^{-}-\mathrm{N}$ concentrations varied along the encroachment gradient (KW, $p<0.001)$, where $\mathrm{NO}_{3}^{-}-\mathrm{N}$ decreased from $1.2 \pm 0.8 \mu \mathrm{g} \mathrm{g}^{-1}$ at S-4 to $0.5 \pm 0.2 \mu \mathrm{g} \mathrm{g}^{-1}$ at S-44, and subsequently rose to $2.5 \pm 0.2 \mu \mathrm{gg}^{-1} \mathrm{~S}-56$ (Fig. 5c). No such trend was identified in the $\mathrm{NO}_{3}^{-}-\mathrm{N}$ con- 
Table 1. Median textural characteristics, dry matter content (DMC), and pH (1:5 soil: $0.01 \mathrm{M} \mathrm{CaCl}_{2}$ ) for the surface soil layer (top $10 \mathrm{~cm}$ ) beneath inter-shrub (IS) and shrub (S) canopy cover types along a gradient of shrub encroachment in a semi-arid grassland of the Santa Rita Experimental Range, AZ, US. Values in parentheses represent 1 median absolute deviation about the median.

\begin{tabular}{|c|c|c|c|c|c|c|c|c|c|c|}
\hline & \multicolumn{10}{|c|}{ Site } \\
\hline & \multicolumn{2}{|c|}{ S-4 } & \multicolumn{2}{|c|}{ S-28 } & \multicolumn{2}{|c|}{ S-44 } & \multicolumn{2}{|c|}{ S-55 } & \multicolumn{2}{|c|}{ S-56 } \\
\hline & IS & S & IS & $S$ & IS & $S$ & IS & $S$ & IS & S \\
\hline$\%$ coarse $^{\mathrm{a}, \mathrm{b}, \mathrm{g}}$ & $\begin{array}{l}11.4 \\
(2.7)\end{array}$ & $\begin{array}{r}11.0 \\
(7.1)\end{array}$ & $\begin{array}{r}18.0 \\
(4.8)\end{array}$ & $\begin{array}{l}17.6 \\
(2.9)\end{array}$ & $\begin{array}{r}18.0 \\
(4.0)\end{array}$ & $\begin{array}{l}18.4 \\
(4.8)\end{array}$ & $\begin{array}{l}24.7 \\
(2.3)\end{array}$ & $\begin{array}{l}24.3 \\
(4.6)\end{array}$ & $\begin{array}{r}16.5 \\
(5.0)\end{array}$ & $\begin{array}{c}19.3 \\
(7.6)\end{array}$ \\
\hline$\%$ clay $\mathrm{c}, \mathrm{d}, \mathrm{g}$ & $\begin{array}{r}1.6 \\
(0.3)\end{array}$ & $\begin{array}{r}0.8 \\
(0.6)\end{array}$ & $\begin{array}{r}2.2 \\
(0.3)\end{array}$ & $\begin{array}{r}0.2 \\
(0.1)\end{array}$ & $\begin{array}{r}1.5 \\
(0.2)\end{array}$ & $\begin{array}{r}0.1 \\
(0.0)\end{array}$ & $\begin{array}{r}1.5 \\
(0.2)\end{array}$ & $\begin{array}{r}0.2 \\
(0.1)\end{array}$ & $\begin{array}{r}1.7 \\
(0.3)\end{array}$ & $\begin{array}{r}0.3 \\
(0.3)\end{array}$ \\
\hline$\%$ silt $^{\mathrm{c}}, \mathrm{e}, \mathrm{g}$ & $\begin{array}{l}41.9 \\
(3.6)\end{array}$ & $\begin{array}{r}49.5 \\
(15.4)\end{array}$ & $\begin{array}{c}53.5 \\
(3.5)\end{array}$ & $\begin{array}{l}36.2 \\
(3.3)\end{array}$ & $\begin{array}{r}47.9 \\
(8.9)\end{array}$ & $\begin{array}{l}53.5 \\
(3.5)\end{array}$ & $\begin{array}{r}35.7 \\
(5.1)\end{array}$ & $\begin{array}{l}40.3 \\
(5.6)\end{array}$ & $\begin{array}{r}39.2 \\
(6.0)\end{array}$ & $\begin{array}{c}35.4 \\
(6.1)\end{array}$ \\
\hline$\%$ sand $^{\mathrm{c}, \mathrm{f}, \mathrm{g}}$ & $\begin{array}{l}56.9 \\
(3.1)\end{array}$ & $\begin{array}{r}49.7 \\
(16.0)\end{array}$ & $\begin{array}{r}44.4 \\
(4.2)\end{array}$ & $\begin{array}{r}63.7 \\
(3.3)\end{array}$ & $\begin{array}{r}44.9 \\
(9.5)\end{array}$ & $\begin{array}{l}44.4 \\
(4.2)\end{array}$ & $\begin{array}{c}64.2 \\
(5.0)\end{array}$ & $\begin{array}{r}59.5 \\
(5.8)\end{array}$ & $\begin{array}{c}57.6 \\
(7.4)\end{array}$ & $\begin{array}{r}64.3 \\
(6.3)\end{array}$ \\
\hline$\% \mathrm{DMC}^{\mathrm{c}, \mathrm{g}}$ & $\begin{array}{l}99.1 \\
(0.1)\end{array}$ & $\begin{array}{r}99.0 \\
(0.1)\end{array}$ & $\begin{array}{r}99.1 \\
(0.0)\end{array}$ & $\begin{array}{l}98.9 \\
(0.2)\end{array}$ & $\begin{array}{r}99.3 \\
(0.2)\end{array}$ & $\begin{array}{l}98.8 \\
(0.2)\end{array}$ & $\begin{array}{r}98.9 \\
(0.1)\end{array}$ & $\begin{array}{l}98.5 \\
(0.1)\end{array}$ & $\begin{array}{r}98.7 \\
(0.2)\end{array}$ & $\begin{array}{l}98.8 \\
(0.3)\end{array}$ \\
\hline $\mathrm{pH}^{\mathrm{c}, \mathrm{h}}$ & $\begin{array}{r}6.3 \\
(0.4)\end{array}$ & $\begin{array}{r}4.9 \\
(0.1)\end{array}$ & $\begin{array}{r}5.3 \\
(0.1)\end{array}$ & $\begin{array}{r}5.7 \\
(0.5)\end{array}$ & $\begin{array}{r}5.2 \\
(0.1)\end{array}$ & $\begin{array}{r}5.5 \\
(0.3)\end{array}$ & $\begin{array}{r}5.1 \\
(0.1)\end{array}$ & $\begin{array}{r}6.0 \\
(0.0)\end{array}$ & $\begin{array}{r}4.7 \\
(0.5)\end{array}$ & $\begin{array}{r}6.0 \\
(0.2)\end{array}$ \\
\hline
\end{tabular}

${ }^{\mathrm{a}}$ Total soil $(>0 \mu \mathrm{m}) .{ }^{\mathrm{b}}>2000 \mu \mathrm{m} .{ }^{\mathrm{c}}$ Fine earth fraction only $(\leq 2000 \mu \mathrm{m}) .{ }^{\mathrm{d}}<2 \mu \mathrm{m} .{ }^{\mathrm{e}} 2-50 \mu \mathrm{m} .{ }^{\mathrm{f}}>50-2000 \mu \mathrm{m} . \mathrm{g}_{n}=9 .{ }^{h} n=3$.
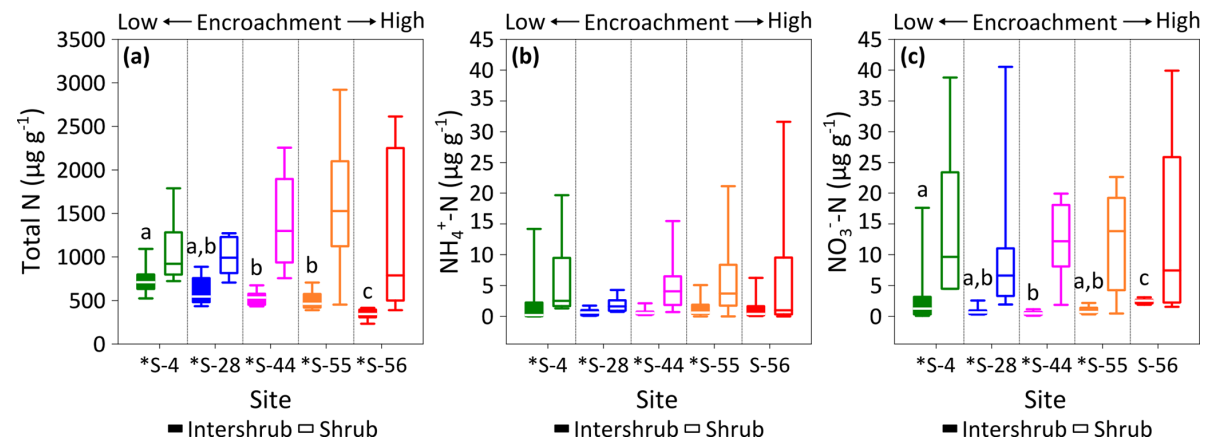

Figure 5. Total $\mathrm{N}(\mathbf{a}), \mathrm{NH}_{4}^{+}-\mathrm{N}(\mathbf{b})$, and $\mathrm{NO}_{3}^{-}-\mathrm{N}$ (c) concentrations for surface soil (top $10 \mathrm{~cm}$ ) by dry weight under inter-shrub and shrub cover types along a shrub encroachment gradient in the Santa Rita Experimental Range, AZ, US $(n=9)$. Boxes denoted with different letters indicate significant differences by cover type at $p<0.05$ (Dunn's test). Inter-shrub and shrub soils at sites denoted with an asterisk differ significantly from each other at $p<0.05$ (Mann-Whitney $U$ test).

centrations of shrub soils, which instead remained constant along the encroachment gradient (KW, $p>0.05$ ).

To identify site-level changes in the surface $\mathrm{N}$ pools, total area-weighted concentrations of total $\mathrm{N}, \mathrm{NH}_{4}^{+}-\mathrm{N}$, and $\mathrm{NO}_{3}^{-}-\mathrm{N}$ were calculated for each site according to percentage inter-shrub and shrub cover (Fig. 1b). Overall, site-level total $\mathrm{N}$ concentrations (Fig. 6a) did not change with increasing shrub encroachment (KW, $p>0.05)$. However, the proportion of total $\mathrm{N}$ contained within the inorganic fraction increased in relation to the degree of shrub encroachment. Such increases were largely seen in the form of $\mathrm{NO}_{3}^{-}-\mathrm{N}$ (Fig. 6c), which increased from $0.2 \pm 0.1$ to $0.6 \pm 0.3 \mathrm{~g} \mathrm{~m}^{-2}$ between sites S-4 and S-56 (DT, $p<0.05$ ). Concentrations of $\mathrm{NH}_{4}^{+}-\mathrm{N}$ experienced an increase from $0.03 \pm 0.03 \mathrm{~g} \mathrm{~m}^{-2}$ at S-4 to $0.2 \pm 0.1 \mathrm{~g} \mathrm{~m}^{-2}$ at S-55 (Fig. 6b), but ultimately did not differ among the end-member sites (DT, $p>0.05$ ).

\subsection{Nutrient ratios}

Ratios of SOC: total N (C:N) did not differ across the encroachment gradient for either cover type (KW, $p>0.05$ ). The average $\mathrm{C}: \mathrm{N}$ ratios for inter-shrub and shrub soils were 7.0 and 7.7, respectively (Fig. 7a), and these did not differ among cover types at any of the five sites (MW, $p>0.05$ ). Similarly, inorganic $\mathrm{N}$ : bioavailable $\mathrm{P}(\mathrm{N}: \mathrm{P})$ ratios (Fig. $7 \mathrm{~b})$ for inter-shrub $(p>0.05)$ and shrub $(\mathrm{KW}, p>0.05)$ soils did not differ significantly among sites, where the respective mean ratios for inter-shrub and shrub soils were 0.1 and 1.2. However, shrub soil N:P ratios exhibited a high degree of variability and were greater than those of inter-shrub soils for all sites (MW, $p<0.05$ ) except S-56 (MW, $p>0.05$ ). 

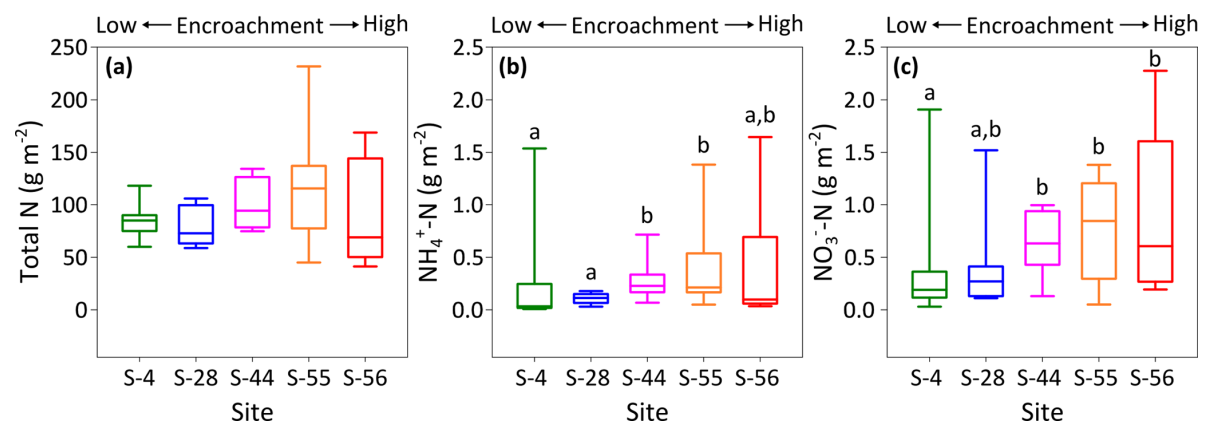

Figure 6. Site-level total $\mathrm{N}(\mathbf{a}), \mathrm{NH}_{4}^{+}-\mathrm{N}(\mathbf{b})$, and $\mathrm{NO}_{3}^{-}-\mathrm{N}$ (c) concentrations (dry matter) weighted by relative area of inter-shrub to shrub cover for surface soil (top $10 \mathrm{~cm}$ ) along a gradient of shrub encroachment in the Santa Rita Experimental Range, AZ, US ( $n=9$ ). Boxes denoted with alternative letters differ significantly from one another at $p<0.05$ (Dunn's test).


Figure 7. SOC : total $\mathrm{N}$ (a) and inorganic $\mathrm{N}$ : bioavailable $\mathrm{P}$ (b) ratios for surface soil (top $10 \mathrm{~cm}$ ) under inter-shrub and shrub cover types along a shrub encroachment gradient in the Santa Rita Experimental Range, AZ, US $(n=9)$. Inter-shrub and shrub soils at sites denoted with an asterisk differ significantly from each other at $p<0.05$ (Mann-Whitney $U$ test).

\subsection{Microbial biomass}

No trends were observed in bacterial PLFA biomass across the shrub encroachment gradient (Fig. 8a). The greatest $\left(3.6 \pm 0.1 \mathrm{nmol} \mathrm{g}^{-1}\right)$ bacterial PLFA concentrations were found in the inter-shrub soils at S-44 and the lowest $(0.6 \pm$ $0.1 \mathrm{nmol} \mathrm{g}^{-1}$ ) in inter-shrub soils at S-56. The fungal PLFA biomass of inter-shrub soils was less variable in comparison with the bacterial PLFA biomass and decreased from a maximum concentration of $0.2 \pm 0.1 \mathrm{nmol} \mathrm{g}^{-1}$ at S-4 across the encroachment gradient, where concentrations were below the limits of detection at both S-28 and S-56 (Fig. 8b). Similarly, the fungal PLFA content of shrub soils, which was typically greater, but more variable than that of inter-shrub soils, decreased steadily from $0.3 \pm 0.1$ to $0.05 \pm 0.05 \mathrm{nmol} \mathrm{g}^{-1}$ among end-member sites, where fungal PLFA concentrations were below the limits of detection at S-55. Consequently, the fungal-to-bacterial ratio decreased under both shrub and inter-shrub soils with increasing shrub encroachment.
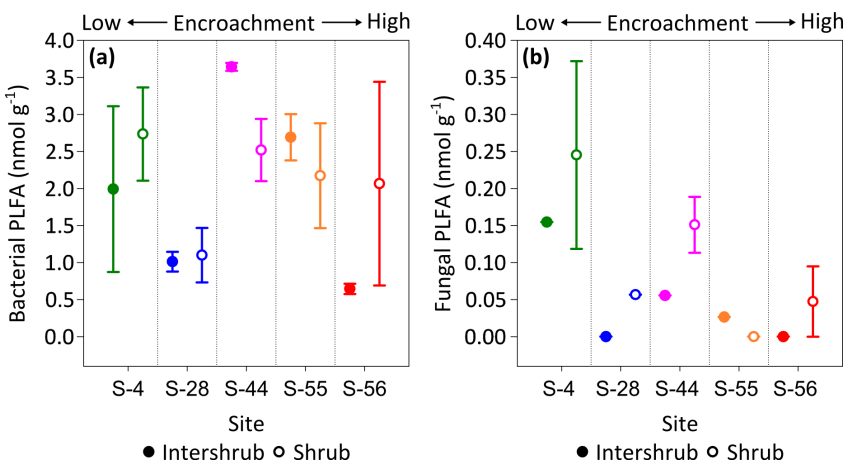

Figure 8. Median bacterial (a) and fungal (b) phospholipid fatty acid (PLFA) concentrations for surface soil (top $10 \mathrm{~cm}$ ) along a gradient of shrub encroachment in the Santa Rita Experimental Range, AZ, US $(n=3)$. Error bars represent median absolute deviation about the median. All results are reported on a dry matter basis.

\subsection{Acetylene reduction assay}

Rates of $\mathrm{C}_{2} \mathrm{H}_{2}$ reduction were only above the limits of detection in inter-shrub soils at sites S-4 and S-44, where rates of $\mathrm{C}_{2} \mathrm{H}_{4}$ production were linear over the $24 \mathrm{~h}$ incubation period $\left(R^{2}=0.97\right.$ for S- 4 , and $R^{2}=0.84$ for S- 44 ; slopes of regression lines were significantly different from zero for both $\mathrm{S}-4$ $(p<0.001)$ and S-44 $(p<0.01)$; data not shown here). When converted to annual rates of $\mathrm{N}$ fixation per unit area (Fig. 9a), inputs of $\mathrm{N}$ by asymbiotic BNF were similar between sites S-4 $\left(2.4 \mathrm{~g} \mathrm{~N} \mathrm{~m}^{-2} \mathrm{a}^{-1}\right)$ and S-44 $\left(2.5 \mathrm{~g} \mathrm{~N} \mathrm{~m}^{-2} \mathrm{a}^{-1}\right)$. However, when adjusted for percentage cover (Fig. 9b), rates of asymbiotic BNF declined in relation to reductions in inter-shrub area from $2.3 \mathrm{~g} \mathrm{~N} \mathrm{~m}^{-2} \mathrm{a}^{-1}$ at S-4 to $1.4 \mathrm{~g} \mathrm{~N} \mathrm{~m}^{-2} \mathrm{a}^{-1}$ at S-44.

\section{Discussion}

Our study revealed the distribution and speciation of soil $\mathrm{N}$, as well as the extent of nitrogenase activity, are strongly influenced by the degree of shrub encroachment in a semi-arid grassland of the SRER. Yet, overall, the soil N pool incurred 

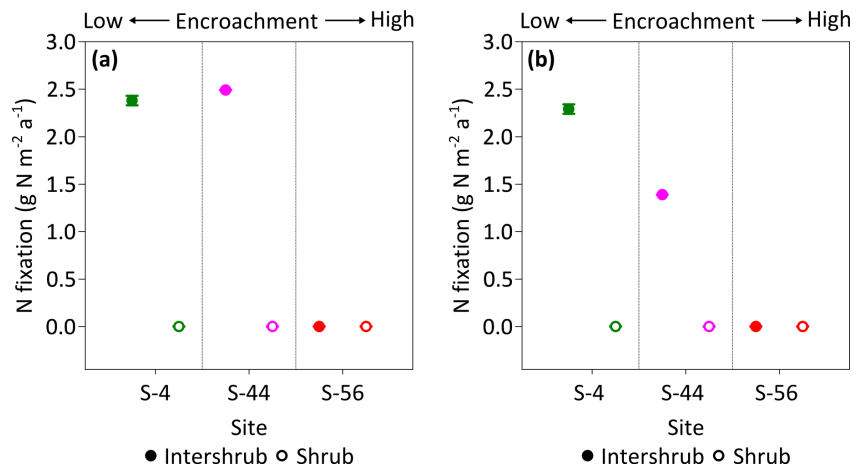

Figure 9. Median rates of asymbiotic nitrogen $(\mathrm{N})$ fixation for intershrub and shrub surface (top $10 \mathrm{~cm}$ ) soil (a) and inter-shrub and shrub surface soil weighted by area cover (b) along a gradient of shrub encroachment in the Santa Rita Experimental Range, AZ, US $(n=3)$. Error bars represent median absolute deviation about the median. $\mathrm{N}$ fixation rates were determined using the acetylene reduction assay method in which ethylene was converted to $\mathrm{N}_{2}$ using a $3: 1$ ratio (Telling et al., 2011). Results are reported on a dry matter basis.

no net change with the transition from a grass- to shrubdominated state. Below we discuss specifically how the soil $\mathrm{N}$ pool responds to increasing shrub cover and how changes in the soil microbial biomass and nutrient ratios associated with shrub encroachment influence $\mathrm{N}$ inputs by asymbiotic BNF in a semi-arid grassland.

\subsection{Distribution and speciation of soil nitrogen}

Like other studies for the southwestern US (e.g. Wheeler et al., 2007; Turnbull et al., 2010; Schlesinger et al., 1996; Michaelides et al., 2012), we determined that concentrations of total $\mathrm{N}$ are greater in surface soils under shrubs relative to inter-shrub areas for all sites along the encroachment gradient (Fig. 5a-c). Further, whilst concentrations of total $\mathrm{N}$ in shrub soils are not statistically separable, we found the total $\mathrm{N}$ content of inter-shrub soils declined among end-member sites coincident with reductions in herbaceous biomass (Fig. 4a) and cover (Fig. 1b). As site-level concentrations of total $\mathrm{N}$ remained constant with increasing shrub cover (Fig. 6a), the accumulation of $\mathrm{N}$ beneath shrub canopies can be considered a direct consequence of $\mathrm{N}$ losses from inter-shrub soils. These findings contrast with studies which identified net increases (e.g. Boutton and Liao, 2010) and declines (e.g. Jackson et al., 2002) in the total $\mathrm{N}$ pool with shrub encroachment but support the widely held perspective that transitions from continuous grass- to shrub-dominated states increase the spatial heterogeneity of soil resources (D'Odorico et al., 2013; Peters et al., 2006; Schlesinger et al., 1990).

Organic N (total $\mathrm{N}$ minus inorganic $\mathrm{N}$ ) comprises $>98 \%$ of total $\mathrm{N}$ in all inter-shrub and shrub soils (Fig. 5a-c). Thus, the elevated concentrations of total $\mathrm{N}$ in shrub soils, which are $\geq 1.5$ times those of inter-shrub soils, represent larger stores of mineralisable $\mathrm{N}$. Rates of $\mathrm{N}$ mineralisation are inversely related to soil $\mathrm{C}: \mathrm{N}$ ratios (Finzi et al., 1998), which in turn have been shown to decrease under mesquite canopies in response to inputs of higher-quality litter (Geesing et al., 2000; Throop and Archer, 2007). However, like Wheeler et al. (2007), we found that soil $\mathrm{C}: \mathrm{N}$ ratios, which are lower than those previously reported for the area (Wheeler et al., 2007), are not affected by shrub encroachment processes in the SRER (Fig. 7a). Whilst this could be due in part to depressed subcanopy soil-litter mixing (Throop and Archer, 2008), the accumulation (and flux) of $\mathrm{N}$ has been shown to share a positive relationship with the soil clay content (Virginia and Jarrell, 1983; Michaelides et al., 2012), which was lower in soils beneath shrub canopies relative to those from inter-shrub areas (Table 1). Nevertheless, shrub soils contain greater concentrations of $\mathrm{NH}_{4}^{+}-\mathrm{N}$ and $\mathrm{NO}_{3}^{-}-\mathrm{N}$ than intershrub soils at all sites except S-56 (Fig. 5b, c), which suggests the microbial community beneath shrub canopies can mineralise organic forms of $\mathrm{N}$ more readily. This is supported by a study for a semi-arid grassland in central Spain, which showed the availability of inorganic $\mathrm{N}$ is largely influenced by the abundance and functional diversity of the microbial community (Delgado-Baquerizo et al., 2015).

In this study, bacterial PLFA concentrations did not follow a clear trend with increasing shrub encroachment (Fig. 8a), whereas the fungal PLFA content of both inter-shrub and shrub soils decreased linearly among end-member sites (Fig. 8b). These results contrast with previous studies, which found the microbial biomass to be greater in soils beneath shrub canopies than adjacent grasses due to reduced environmental stress and greater stores of SOM (Gallardo and Schlesinger, 1992; Li et al., 2017; Ewing et al., 2007). As ratios between the fungal and bacterial constituents of the microbial community share a negative relationship with soil $\mathrm{pH}$ (Bååth and Anderson, 2003), a decline in the fungal PLFA content of shrub soils can be attributed to changes in shrub soil $\mathrm{pH}$, which increased with gains in shrub cover (Table 1). However, the same cannot be ascribed to changes in the fungal PLFA content of inter-shrub soils, as declines among endmember sites occurred with decreases in soil $\mathrm{pH}$. Instead, if total $\mathrm{N}$ is used as a proxy for SOC (inter-shrub soil C: $\mathrm{N}$ ratios do not differ among sites), reductions in inter-shrub fungal PLFA concentrations with increasing encroachment may be indicative of $\mathrm{C}$ limitation for growth, which would be expected to reduce the microbial biomass and release inorganic $\mathrm{N}$ (Cookson et al., 2006). Accordingly, in addition to an absence of fungal PLFAs, inter-shrub soil at S-56 exhibits the lowest bacterial PLFA content in comparison with all other soils along the encroachment gradient, as well as the highest concentration $\mathrm{NO}_{3}^{-}-\mathrm{N}$ within the inter-shrub soils (Fig. 5c). As fungi have been shown to preferentially utilise grassland C (Creamer et al., 2016), declines in the shrub soil fungal PLFA content with increasing encroachment may also be a response to the progressive depletion of grass-derived SOC. 
It must be noted that we recommend caution when interpreting the vegetation cover and biomass data presented here. The classification accuracy of cover estimates, which are subject to image spatial resolution, as well as land-cover spatial and spectral heterogeneity (Hu et al., 2013), was not formally assessed. Likewise, woody and herbaceous biomass estimates were derived from allometric relationships that had not been ground-truthed and which could potentially vary by soil type, surface morphology, and disturbance history (Nafus et al., 2009; McClaran et al., 2013). However, as relative changes in percentage grass and shrub cover can explain concurrent changes in grass and shrub biomass (Fig. 4c, d), these estimates were useful for capturing the extent of shrub encroachment at each site.

\subsection{Inputs of asymbiotically fixed nitrogen}

In this study we explored a gap in the literature concerning the impacts of increasing shrub encroachment (at sites S-4, S-44, and S-56 only) on the rates and distribution of asymbiotic BNF in a semi-arid grassland. We found that asymbiotic BNF was only detectable in inter-shrub soils at sites S-4 and S-44 (Fig. 9a), which exhibited significantly lower N : P ratios than adjacent shrub soils (Fig. 7b). These findings reinforce the theory that increases in inorganic $\mathrm{N}$ relative to available $\mathrm{P}$ inhibit nitrogenase activity, the enzyme responsible for mediating the adenosine triphosphate reduction of $\mathrm{N}_{2}$ to ammonia in BNF (Smith, 1992). However, despite inter-shrub soil $\mathrm{N}$ : $\mathrm{P}$ ratios remaining constant with increasing encroachment, there was an absence of asymbiotic BNF at S-56. As asymbiotic diazotrophs (N-fixing organisms) are largely contained within the bacterial fraction of the microbial biomass (Poly et al., 2001), the undetectable rates of asymbiotic BNF at S-56 could be attributed to the low bacterial PLFA concentration at this site (Fig. 8a). This conclusion is supported by increases in asymbiotic BNF rates with gains in the bacterial PLFA content of inter-shrub soils between sites S-4 and S-44.

When weighted by inter-shrub area, rates of asymbiotic BNF declined from $2.3 \mathrm{~g} \mathrm{~N} \mathrm{~m}^{-2} \mathrm{a}^{-1}$ at $\mathrm{S}-4$ to $1.4 \mathrm{~g} \mathrm{~N} \mathrm{~m}^{-2} \mathrm{a}^{-1}$ at $\mathrm{S}-44$ (Fig. 9b). As levels of total $\mathrm{N}$ deposition $\left(0.1-0.2 \mathrm{~g} \mathrm{~N} \mathrm{~m}^{-2} \mathrm{a}^{-1}\right)$ in the southwestern US are generally low (Schwede and Lear, 2014), the decreasing rates of BNF associated with increasing site-level concentrations of inorganic $\mathrm{N}$ (Fig. 6b, c) with shrub encroachment represent the loss of a significant $\mathrm{N}$ input pathway to these already N-limited systems, which Belnap (1995) argues may not be readily recovered. However, the rates of asymbiotic BNF reported here, which exceed previous estimates for dryland systems by an order of magnitude (Cleveland et al., 1999), represent an absolute upper limit as soil moisture, temperature, and light were maintained during the incubation experiments. Constant incubation parameters were used to achieve linear rates of $\mathrm{C}_{2} \mathrm{H}_{2}$ reduction over a $24 \mathrm{~h}$ period, in which parameters were chosen to reflect mean summer conditions when microbial activity is greatest due to increased soil water availability (Loik et al., 2004).

A study by Geesing et al. (2000) showed the development of the soil $\mathrm{N}$ pool beneath mesquite canopies is attributable to inputs of symbiotically fixed N. As site-level concentrations of total $\mathrm{N}$ do not differ between end-member sites, we argue the loss of inter-shrub soil $\mathrm{N}$ and asymbiotic BNF with shrub encroachment seen here is balanced by inputs of symbiotically fixed $\mathrm{N}$ by mesquite. However, as the redistribution of soil resources with shrub encroachment modifies the development of shrub over inter-shrub soils, inputs of $\mathrm{N}$ by mesquite-Rhizobium symbioses are ultimately unavailable to sustain grass production in inter-shrub areas. Consequently, transitions from grass- to shrub-dominated semi-arid systems may be viewed as a shift between bistable states from which inter-shrub areas may not readily recover (D'Odorico et al., 2013).

\section{Conclusions}

Over the past century, the semi-arid grasslands of the southwestern US have been degraded by the encroachment of mesquite, an N-fixing shrub. From this comprehensive study, we found that as declines in the inter-shrub soil $\mathrm{N}$ pool were proportional to increases in soils under shrub canopies, the site-level soil $\mathrm{N}$ pool remained constant along a gradient of increasing shrub cover within a semi-arid grassland of the SRER. Yet the inorganic fraction of the site-level soil $\mathrm{N}$ pool increased with shrub area and biomass due to the longterm accumulation of $\mathrm{NH}_{4}^{+}-\mathrm{N}$ and $\mathrm{NO}_{3}^{-}-\mathrm{N}$ in soils beneath shrub canopies. Considering soil $\mathrm{C}: \mathrm{N}$ ratios did not differ among sites or cover type, increases in concentrations of inorganic $\mathrm{N}$ in shrub soils were attributed to the capacity of the soil microbial community to mineralise organic forms of $\mathrm{N}$. Finally, as the ratio of inorganic $\mathrm{N}$ to bioavailable $\mathrm{P}$ has been shown to influence nitrogenase activity, we explored the effects of shrub encroachment on the distribution and rates of asymbiotic BNF in the grassland soil. We found that BNF was inhibited by higher concentrations of inorganic $\mathrm{N}$ to available $\mathrm{P}$ and, when weighted by inter-shrub area, provided a lower input of new $\mathrm{N}$ to the system with increasing shrub cover. The loss of this ecosystem process, as well as declines in the inter-shrub soil $\mathrm{N}$ pool, were potentially balanced by inputs of symbiotically fixed $\mathrm{N}$ by mesquite. Consequently, we conclude the long-term accumulation of $\mathrm{N}$ beneath shrub canopies combined with increases in shrub canopy area have the potential to significantly change the dynamics of soil $\mathrm{N}$ cycling in dryland systems. 
Data availability. All data presented in Figs. 4-9 are available online (Turpin-Jelfs and Michaelides, 2018).

Author contributions. TTJ led the design of the study, assisted by $\mathrm{KM}$ and AMA. All sample collection and analyses were performed by TTJ. TTJ wrote the paper with contributions from KM, JAB, and AMA.

Competing interests. The authors declare that they have no conflict of interest.

Acknowledgements. The research was supported by a University of Bristol Graduate Teaching Studentship to Thomas Turpin-Jelfs, a NERC LSMSF grant BRIS/103/07/17 to Katerina Michaelides for PLFA analysis and a NERC grant NE/J02399X/1 to Alexandre M. Anesio for fieldwork expenses. We thank the USDA for allowing us to use facilities in Tucson, AZ, during field campaigns, as well as Francine Turpin, Isaac Turpin, and Joshua Turpin for assisting with the analysis of samples during their individual work experience placements at the University of Bristol.

Edited by: Lutz Merbold

Reviewed by: two anonymous referees

\section{References}

Arganda-Carreras, I., Kaynig, V., Rueden, C., Eliceiri, K. W., Schindelin, J., Cardona, A., and Sebastian Seung, H.: Trainable Weka Segmentation: a machine learning tool for microscopy pixel classification, Bioinformatics, 33, 2424-2426, https://doi.org/10.1093/bioinformatics/btx180, 2017.

Bååth, E. and Anderson, T. H.: Comparison of soil fungal/bacterial ratios in a $\mathrm{pH}$ gradient using physiological and PLFA-based techniques, Soil Biol. Biochem., 35, 955-963, https://doi.org/10.1016/S0038-0717(03)00154-8, 2003.

Batchily, A. K., Post, D. F., Bryant, R. B., and Breckenfeld, D. J.: Spectral reflectance and soil morphology characteristics of Santa Rita Experimental Range soils, Santa Rita Experimental Range: 100 Years (1903 to 2003) of Accomplishments and Contributions, Tucson, AZ, 2003, 175-182, 2003.

Belnap, J.: Surface disturbances: their role in accelerating desertification, Environ. Monit. Assess., 37, 39-57, https://doi.org/10.1007/BF00546879, 1995.

Bennett, L. T., Judd, T. S., and Adams, M. A.: Growth and nutrient content of perennial grasslands following burning in semi-arid, sub-tropical Australia, Plant Ecol., 164, 185-199, https://doi.org/10.1023/A:1021253600712, 2003.

Blaser, W. J., Shanungu, G. K., Edwards, P. J., and Olde Venterink, H.: Woody encroachment reduces nutrient limitation and promotes soil carbon sequestration, Ecol. Evolut., 4, 1423-1438, https://doi.org/10.1002/ece3.1024, 2014.

Bligh, E. G. and Dyer, W. J.: A rapid method of total lipid extraction and purification, Can. J. Biochem. Phys., 37, 911-917, https://doi.org/10.1139/o59-099, 1959.
Boutton, T. W. and Liao, J. D.: Changes in soil nitrogen storage and $\delta^{15} \mathrm{~N}$ with woody plant encroachment in a subtropical savanna parkland landscape, J. Geophys. Res.-Biogeo., 115, G03019, https://doi.org/10.1029/2009JG001184, 2010.

Browning, D. M., Archer, S. R., Asner, G. P., McClaran, M. P., and Wessman, C. A.: Woody plants in grasslands: postencroachment stand dynamics, Ecol. Appl., 18, 928-944, https://doi.org/10.1890/07-1559.1, 2008.

Cabral, A. C., Miguel, J. M., Rescia, A. J., Schmitz, M. F., and Pineda, F. D.: Shrub encroachment in Argentinean savannas, J. Veg. Sci. 14, 145-152, https://doi.org/10.1111/j.1654 1103.2003.tb02139.x, 2003.

Charley, J. L. and West, N. E.: Plant-induced soil chemical patterns in some shrub-dominated semi-desert ecosystems of Utah, J. Ecol., 63, 945-963, https://doi.org/10.2307/2258613, 1975.

Christie, W.: Advances in Lipid Methodology-Two, Oily Press, Dundee, 1993.

Cleveland, C. C., Townsend, A. R., Schimel, D. S., Fisher, H., Howarth, R. W., Hedin, L. O., Perakis, S. S., Latty, E. F., Von Fischer, J. C., Elseroad, A., and Wasson, M. F.: Global patterns of terrestrial biological nitrogen $\left(\mathrm{N}_{2}\right)$ fixation in natural ecosystems, Global Biogeochem. Cy., 13, 623-645, https://doi.org/10.1029/1999GB900014, 1999.

Cookson, W. R., Muller, C., O'Brien, P. A., Murphy, D. V., and Grierson, P. F.: Nitrogen dynamics in an Australian semiarid grassland soil, Ecology, 87, 2047-2057, 2006.

Crawley, M. J.: Statistics: An Introduction Using R, John Wiley \& Sons Ltd, Chichester, 2005.

Creamer, C. A., Filley, T. R., Boutton, T. W., and Rowe, H. I.: Grassland to woodland transitions: Dynamic response of microbial community structure and carbon use patterns, J. Geophys. Res.-Biogeo., 121, 1675-1688, https://doi.org/10.1002/2016JG003347, 2016.

Cross, A. F. and Schlesinger, W. H.: Plant regulation of soil nutrient distribution in the northern Chihuahuan Desert, Plant Ecol., 145, 11-25, https://doi.org/10.1023/A:1009865020145, 1999.

D'Odorico, P., Bhattachan, A., Davis, K. F., Ravi, S., and Runyan, C. W.: Global desertification: drivers and feedbacks, Adv. Water Resour., 51, 326-344, https://doi.org/10.1016/j.advwatres.2012.01.013, 2013.

Delgado-Baquerizo, M., Maestre, F. T., Gallardo, A., Bowker, M. A., Wallenstein, M. D., Quero, J. L., Ochoa, V., Gozalo, B., Garcia-Gomez, M., Soliveres, S., Garcia-Palacios, P., Berdugo, M., Valencia, E., Escolar, C., Arredondo, T., Barraza-Zepeda, C., Bran, D., Carreira, J. A., Chaieb, M., Conceicao, A. A., Derak, M., Eldridge, D. J., Escudero, A., Espinosa, C. I., Gaitan, J., Gatica, M. G., Gomez-Gonzalez, S., Guzman, E., Gutierrez, J. R., Florentino, A., Hepper, E., Hernandez, R. M., HuberSannwald, E., Jankju, M., Liu, J., Mau, R. L., Miriti, M., Monerris, J., Naseri, K., Noumi, Z., Polo, V., Prina, A., Pucheta, E., Ramirez, E., Ramirez-Collantes, D. A., Romao, R., Tighe, M., Torres, D., Torres-Diaz, C., Ungar, E. D., Val, J., Wamiti, W., Wang, D., and Zaady, E.: Decoupling of soil nutrient cycles as a function of aridity in global drylands, Nature, 502, 672-676, https://doi.org/10.1038/nature12670, 2013.

Delgado-Baquerizo, M., García-Palacios, P., Milla, R., Gallardo, A., and Maestre, F. T.: Soil characteristics determine soil carbon and nitrogen availability during leaf litter decomposition 
regardless of litter quality, Soil Biol. Biochem., 81, 134-142, https://doi.org/10.1016/j.soilbio.2014.11.009, 2015.

Dickson, L., Bull, I. D., Gates, P. J., and Evershed, R. P.: A simple modification of a silicic acid lipid fractionation protocol to eliminate free fatty acids from glycolipid and phospholipid fractions, J. Microbiol. Methods, 78, 249-254, https://doi.org/10.1016/j.mimet.2009.05.014, 2009.

Eldridge, D. J., Bowker, M. A., Maestre, F. T., Roger, E., Reynolds, J. F., and Whitford, W. G.: Impacts of shrub encroachment on ecosystem structure and functioning: towards a global synthesis, Ecol. Lett., 14, 709-722, https://doi.org/10.1111/j.14610248.2011.01630.x, 2011.

Evans, R. D. and Ehleringer, J. R.: A break in the nitrogen cycle in aridlands? Evidence from $\delta^{15} \mathrm{~N}$ of soils, Oecologia, 94, 314-317, https://doi.org/10.1007/BF00317104, 1993.

Ewing, S. A., Southard, R. J., Macalady, J. L., Hartshorn, A. S., and Johnson, M. J.: Soil microbial fingerprints, carbon, and nitrogen in a Mojave Desert creosote-bush ecosystem, Soil Sci. Soc. Am. J., 71, 469-475, https://doi.org/10.2136/sssaj2005.0283, 2007.

Finzi, A. C., Van Breemen, N., and Canham, C. D.: Canopy tree-soil interactions within temperate forests: species effects on soil carbon and nitrogen, Ecol. Appl., 8, 440-446, https://doi.org/10.1890/10510761(1998)008[0440:CTSIWT]2.0.CO;2, 1998.

Frostegård, Å., Tunlid, A., and Bååth, E.: Microbial biomass measured as total lipid phosphate in soils of different organic content, J. Microbiol. Meth., 14, 151-163, https://doi.org/10.1016/01677012(91)90018-L, 1991.

Gallardo, A. and Schlesinger, W.: Carbon and nitrogen limitations of soil microbial biomass in desert ecosystems, Biogeochemistry, 18, 1-17, https://doi.org/10.1007/BF00000423, 1992.

Gebauer, R. L. E. and Ehleringer, J. R.: Water and nitrogen uptake patterns following moisture pulses in a cold desert community, Ecology, 81, 1415-1424, https://doi.org/10.1890/00129658(2000)081[1415:WANUPF]2.0.CO;2, 2000.

Geesing, D., Felker, P., and Bingham, R. L.: Influence of mesquite (Prosopis glandulosa) on soil nitrogen and carbon development: implications for global carbon sequestration, J. Arid Environ., 46, 157-180, https://doi.org/10.1006/jare.2000.0661, 2000.

Google Earth: Equal Grass Shrub Mix $31^{\circ} 47^{\prime} 38.26^{\prime \prime} \mathrm{N}$, $110^{\circ} 49^{\prime} 29.22^{\prime \prime} \mathrm{W}$, elevation $1,250 \mathrm{~m}, 2016 \mathrm{a}$.

Google Earth: Grass-Dominant with Few Shrubs $31^{\circ} 47^{\prime} 15.06^{\prime \prime} \mathrm{N}$, $110^{\circ} 50^{\prime} 5.29^{\prime \prime} \mathrm{W}$, elevation $1,250 \mathrm{~m}, 2016 \mathrm{~b}$.

Google Earth: Grass-Dominant Shrub Mix, $31^{\circ} 47^{\prime} 16.12^{\prime \prime} \mathrm{N}$, $110^{\circ} 50^{\prime} 34.84^{\prime \prime} \mathrm{W}$, elevation 1,250 m, $2016 \mathrm{c}$.

Google Earth: Shrub-Dominant Grass Mix $31^{\circ} 47^{\prime} 57.39^{\prime \prime} \mathrm{N}$, $110^{\circ} 49^{\prime} 33.13^{\prime \prime} \mathrm{W}$, elevation 1,250 m, $2016 \mathrm{~d}$.

Google Earth: Shrub-Dominant with Bare Intershrub Areas $31^{\circ} 48^{\prime} 9.75^{\prime \prime} \mathrm{N}, 110^{\circ} 50^{\prime} 15.46^{\prime \prime} \mathrm{W}$, elevation $1,250 \mathrm{~m}, 2016 \mathrm{e}$.

Goossens, D., Buck, B. J., Teng, Y., Robins, C., and Goldstein, H. L.: Effect of sulfate and carbonate minerals on particle-size distributions in arid soils, Soil Sci. Soc. Am. J., 78, 881-893, https://doi.org/10.2136/sssaj2013.11.0499, 2014.

Hedges, J. I. and Stern, J. H.: Carbon and nitrogen determinations of carbonate-containing solids, Limnol. Oceanogr., 29, 657-663, https://doi.org/10.4319/1o.1984.29.3.0657, 1984.

Hedley, M. J., Stewart, J. W. B., and Chauhan, B. S.: Changes in inorganic and organic soil phosphorus fractions induced by cultivation practices and by labora- tory incubations, Soil Sci. Soc. Am. J., 46, 970-976, https://doi.org/10.2136/sssaj1982.03615995004600050017x, 1982.

Hu, Q., Wu, W., Xia, T., Yu, Q., Yang, P., Li, Z., and Song, Q.: Exploring the use of Google Earth imagery and object-based methods in land use/cover mapping, Remote Sens., 5, 6026-6042, 2013.

Hudak, A. T., Wessman, C. A., and Seastedt, T. R.: Woody overstorey effects on soil carbon and nitrogen pools in South African savanna, Austral Ecol., 28, 173-181, https://doi.org/10.1046/j.1442-9993.2003.01265.x, 2003.

Jackson, R. B., Banner, J. L., Jobbágy, E. G., Pockman, W. T., and Wall, D. H.: Ecosystem carbon loss with woody plant invasion of grasslands, Nature, 418, 623-626, https://doi.org/10.1038/nature00910, 2002.

Knapp, A. K., Briggs, J. M., Collins, S. L., Archer, S. R., BretHarte, M. S., Ewers, B. E., Peters, D. P., Young, D. R., Shaver, G. R., Pendall, E., and Cleary, M. B.: Shrub encroachment in North American grasslands: shifts in growth form dominance rapidly alters control of ecosystem carbon inputs, Glob. Change Biol., 14, 615-623, https://doi.org/10.1111/j.1365-2486.2007.01512.x, 2008.

Li, H., Zhang, J., Hu, H., Chen, L., Zhu, Y., Shen, H., and Fang, J.: Shift in soil microbial communities with shrub encroachment in Inner Mongolia grasslands, China, Eur. J. Soil Biol., 79, 40-47, https://doi.org/10.1016/j.ejsobi.2017.02.004, 2017.

Loik, M. E., Breshears, D. D., Lauenroth, W. K., and Belnap, J.: A multi-scale perspective of water pulses in dryland ecosystems: climatology and ecohydrology of the western USA, Oecologia, 141, 269-281, https://doi.org/10.1007/s00442-004-1570-y, 2004.

Loveland, P. J. and Whalley, W. R.: Particle size analysis, in: Soil and Environmental Analysis: Physical Methods, 2nd Edn., edited by: Smith, K. A. and Mullins, C. E., Marcel Dekker, Inc., New York, NY, 281-314, 2000.

McClaran, M. P.: A century of vegetation change on the Santa Rita Experimental Range, Santa Rita Experimental Range: 100 years (1903 to 2003) of Accomplishments and Contributions, Tucson, AZ, 2003, 16-33, 2003.

McClaran, M. P., McMurtry, C. R., and Archer, S. R.: A tool for estimating impacts of woody encroachment in arid grasslands: allometric equations for biomass, carbon and nitrogen content in Prosopis velutina, J. Arid Environ., 88, 39-42, https://doi.org/10.1016/j.jaridenv.2012.08.015, 2013.

Michaelides, K., Lister, D., Wainwright, J., and Parsons, A. J.: Vegetation controls on small-scale runoff and erosion dynamics in a degrading dryland environment, Hydrol. Process., 23, 16171630, 2009.

Michaelides, K., Lister, D., Wainwright, J., and Parsons, A. J.: Linking runoff and erosion dynamics to nutrient fluxes in a degrading dryland landscape, J. Geophys. Res.-Biogeo., 117, G00N15, https://doi.org/10.1029/2012JG002071, 2012.

Mumford, P. N.: Nutrient Budgets and Transport Dynamics in a High Arctic Glacier Basin, Svalbard, Ph.D, University of Sheffield, 2003.

Nafus, A. M., McClaran, M. P., Archer, S. R., and Throop, H. L.: Multispecies allometric models predict grass biomass in semidesert rangeland, Rangeland Ecol. Manag., 62, 68-72, https://doi.org/10.2111/08-003, 2009. 
Parsons, A. J., Abrahams, A. D., and Wainwright, J.: Responses of interrill runoff and erosion rates to vegetation change in southern Arizona, Geomorphology, 14, 311-317, https://doi.org/10.1016/0169-555X(95)00044-6, 1996.

Peters, D. P. C., Bestelmeyer, B. T., Herrick, J. E., Fredrickson, E. L., Monger, H. C., and Havstad, K. M.: Disentangling complex landscapes: new insights into arid and semiarid system dynamics, BioScience, 56, 491-501, https://doi.org/10.1641/00063568(2006)56[491:DCLNII]2.0.CO;2, 2006.

Poly, F., Ranjard, L., Nazaret, S., Gourbière, F., and Monrozier, L. J.: Comparison of nifH gene pools in soils and soil microenvironments with contrasting properties, Appl. Environ. Microbiol., 67, 2255-2262, https://doi.org/10.1128/aem.67.5.22552262.2001, 2001.

Quero, J. L., Maestre, F. T., Ochoa, V., García-Gómez, M., and Delgado-Baquerizo, M.: On the importance of shrub encroachment by sprouters, climate, species richness and anthropic factors for ecosystem multifunctionality in semiarid Mediterranean ecosystems, Ecosystems, 16, 1248-1261, https://doi.org/10.1007/?s10021-013-9683-y, 2013.

Ravi, S., Breshears, D. D., Huxman, T. E., and D’Odorico, P.: Land degradation in drylands: interactions among hydrologic-aeolian erosion and vegetation dynamics, Geomorphology, 116, 236245, https://doi.org/10.1016/j.geomorph.2009.11.023, 2010.

Resco de Dios, V., Weltzin, J. F., Sun, W., Huxman, T. E., and Williams, D. G.: Windows of opportunity for Prosopis velutina seedling establishment and encroachment in a semiarid grassland, Perspect. Plant Ecol., 14, 275-282, https://doi.org/10.1016/j.ppees.2012.03.002, 2012.

Rowell, D. L.: Soil Science: Methods \& Applications, Longman Group UK Ltd, London, 1994.

Saxton, K. E. and Rawls, W. J.: Soil water characteristic estimates by texture and organic matter for hydrologic solutions, Soil Sci. Soc. Am. J., 70, 1569-1578, https://doi.org/10.2136/sssaj2005.0117, 2006.

Schlesinger, W. H., Reynolds, J. F., Cunningham, G. L., Huenneke, L. F., Jarrell, W. M., Virginia, R. A., and Whitford, W. G.: Biological feedbacks in global desertification, Science, 247, 10431048, https://doi.org/10.1126/science.247.4946.1043, 1990.

Schlesinger, W. H., Raikes, J. A., Hartley, A. E., and Cross, A. F.: On the spatial pattern of soil nutrients in desert ecosystems, Ecology, 77, 364-374, https://doi.org/10.2307/2265615, 1996.

Schlesinger, W. H. and Pilmanis, A. M.: Plant-soil interactions in deserts, Biogeochemistry, 42, 169-187, 1998.

Schulten, H. R. and Schnitzer, M.: The chemistry of soil organic nitrogen: a review, Biol. Fert. Soils, 26, 1-15, https://doi.org/10.1007/s003740050335, 1997.

Schwede, D. B. and Lear, G. G.: A novel hybrid approach for estimating total deposition in the United States, Atmos. Environ., 92, 207-220, https://doi.org/10.1016/j.atmosenv.2014.04.008, 2014.

Smith, V.: Effects of nitrogen: phosphorus supply ratios on nitrogen fixation in agricultural and pastoral ecosystems, Biogeochemistry, 18, 19-35, https://doi.org/10.1007/BF00000424, 1992.

Telling, J., Anesio, A. M., Tranter, M., Irvine-Fynn, T., Hodson, A., Butler, C., and Wadham, J.: Nitrogen fixation on Arctic glaciers, Svalbard, J. Geophys. Res.-Biogeo., 116, G03039, https://doi.org/10.1029/2010JG001632, 2011.
Throop, H., L. and Archer, S., R.: Interrelationships among shrub encroachment, land management, and litter decomposition in a semidesert grassland, Ecol. Appl., 17, 1809-1823, https://doi.org/10.1890/06-0889.1, 2007.

Throop, H. L. and Archer, S. R.: Shrub (Prosopis velutina) encroachment in a semidesert grassland: spatial-temporal changes in soil organic carbon and nitrogen pools, Glob. Change Biol., 14, 2420-2431, https://doi.org/10.1111/j.1365-2486.2008.01650.x, 2008.

Turnbull, L., Wainwright, J., Brazier, R. E., and Bol, R.: Biotic and abiotic changes in ecosystem structure over a ShrubEncroachment gradient in the Southwestern USA, Ecosystems, 13, 1239-1255, https://doi.org/10.1007/s10021-010-93848,2010

Turpin-Jelfs, T. and Michaelides, K.: Data from Soil nitrogen response to shrub encroachment in a degrading semiarid grassland, University of Bristol, https://doi.org/10.5523/bris.28ck01sp9c48e1zosa7h2c538u, 2018.

USDA-SCS: Procedures for Collecting Soil Samples and Methods of Analysis for Soil Survey, US Department of Agriculture, Washington, DC, 1982.

Virginia, R. A. and Jarrell, W. M.: Soil properties in a mesquite-dominated Sonoran Desert ecosystem, Soil Sci. Soc. Am. J., 47, 138-144, https://doi.org/10.2136/sssaj1983.03615995004700010028x, 1983.

Vitousek, P. M., Hattenschwiler, S., Olander, L., and Allison, S.: Nitrogen and nature, Ambio, 31, 97-101, 2002.

Wainwright, J., Parsons, A. J., and Abrahams, A. D.: Plot-scale studies of vegetation, overland flow and erosion interactions: case studies from Arizona and New Mexico, Hydrol. Process., 14, 2921-2943, 2000.

Waring, B. G., Averill, C., Hawkes, C. V., and Holyoak, M.: Differences in fungal and bacterial physiology alter soil carbon and nitrogen cycling: insights from meta-analysis and theoretical models, Ecol. Lett., 16, 887-894, https://doi.org/10.1111/ele.12125, 2013.

Wheeler, C. W., Archer, S. R., Asner, G. P., and McMurtry, C. R.: Climatic/edaphic controls on soil carbon/nitrogen response to shrub encroachment in desert grassland, Ecol. Appl., 17, 19111928, 2007.

Willis, R. B. and Gentry, C. E.: Automated method for determining nitrate and nitrite in water and soil extracts, Commun. Soil Sci. Plan., 18, 625-636, https://doi.org/10.1080/00103628709367847, 1987.

Willis, R. B., Schwab, G. J., and Gentry, C. E.: Elimination of interferences in the colorimetric analysis of ammonium in water and soil extracts, Commun. Soil Sci. Plan., 24, 1009-1019, https://doi.org/10.1080/00103629309368857, 1993.

Zhang, H.-Y., Yu, Q., Lü, X.-T., Trumbore, S. E., Yang, J.-J., and Han, X.-G.: Impacts of leguminous shrub encroachment on neighboring grasses include transfer of fixed nitrogen, Oecologia, 180, 1213-1222, https://doi.org/10.1007/s00442-015-3538$5,2016$. 